\title{
Fetal metabolism and fetal growth
}

\author{
C. T. Jones \\ The Nuffield Institute for Medical Research, University of Oxford, Oxford, OX3 9DS, U.K.
}

\begin{abstract}
Although a great deal is known about the metabolism of fetal tissues (Roux \& Yoshioka, 1970; Jost \& Picon, 1970; Stave, 1970; Greengard, 1971) there is no direct information about the influence the fetal metabolism exerts in the control of fetal growth. The assessment of any interrelationships has to be inferential, largely through an analysis of differences in fetal metabolism associated with variations in the fetal growth rate. There appear to be three major factors regulating fetal growth. The first is the maternal organism, by means of its control over the supply of nutrients and hormones to the fetus through its own metabolic activities and by its influence on the placental blood supply. The second is the placenta which may affect fetal growth through the production and transport of substances to the fetus. The third is fetal metabolism itself. Clearly these three components are interdependent, and the relative contribution of each to the control of fetal growth is difficult to determine.
\end{abstract}

\section{Maternal metabolism and fetal growth}

The large changes that occur in maternal metabolism during severe dietary restriction or diabetic pregnancy are associated with substantial modifications of fetal growth. Diabetic pregnancy, either naturally occurring in man (Cardell, 1953; Pedersen, 1967) or experimentally induced in primates (Mintz, Chez \& Hutchinson, 1972), produce a neonate with a much larger birth weight than normal. In such infants the weights of most organs, particularly adipose tissue, are increased and this is reflected in an increase in body protein, fat and glycogen (Fee \& Weil, 1963; Naeye, 1965; Osler, 1965; Glinsmann, Eisen, Lynch \& Chez, 1975). The increased growth rate in utero is thought to result largely from the maternal and concomitant fetal hyperglycaemia (Cornblath \& Schwartz, 1966; Pedersen, 1967; Baird, 1969; Adam, 1971). When the blood glucose is closely controlled the birth weight of infants born to diabetic mothers appears to be reduced (Oakley, 1965; Essex, Pyke, Watkins, Brudenell \& Gamsu, 1973; Persson, 1974).

Reduction of food intake produces large changes in carbohydrate, lipid and amino acid metabolism. During pregnancy this is associated with intrauterine growth retardation, particularly of extra-neural organs, with major alterations of lipid, carbohydrate and amino acid metabolism (Lee \& Chow, 1965; Fain \& Scow, 1966; Zamenhof, Van Marthens \& Margolis, 1968; Chase, Dabiere, Welch \& O'Brien, 1971; Tsoulos, Colwill, Battaglia, Makowski \& Meschia, 1971; Thaler, 1972; Nitzan \& Groffman, 1971; Widdowson, 1974). A similar growth retardation effect can be produced by modifying uterine blood flow to the placenta or umbilical blood flow to the fetus (Wigglesworth, 1964; Hohenauer \& Oh, 1969; Emmanouilides, Townsend \& Bauer, 1968; Roux, Tordet-Caridroit \& Chanez, 1970; Hill, 1974). This can produce major changes in carbohydrate metabolism in fetal tissues and possibly impair the postnatal development of gluconeogenesis (Nitzan \& Groffman, 1971, 1974).

Thus it is likely that the provision of nutrients from the mother to the fetus is controlled both by their concentration in the maternal circulation and the blood supply to the placenta. If, as for fatty acids, the maternal plasma concentration is increased in conditions such as starvation, the supply to the fetus may show a dramatic increase (Widdowson, 1974; Edson, Hudson \& Hull, 1975); this relationship may not, however, be a simple one (Table 1). A similar situation exists for glucose in sheep in that its uptake by the fetus appears to be directly related to the maternal plasma glucose concentration (Battaglia \& Meschia, 1973). A reduction in the supply of glucose to the fetus, as produced by a restriction of uterine blood flow, causes a partial inhibition of hepatic glycogen formation which can be counteracted by a maternal glucose infusion (Oh, D'Amodio, Yap \& Hohenauer, 1970; Nitzan \& Groffman, 1974). 
Table 1. The relationship of fetal weight to hepatic triglyceride concentration in near-term fetal guinea-pigs

\begin{tabular}{lcccc}
\hline & $\begin{array}{c}\text { Body wt } \\
(\mathrm{g})\end{array}$ & $\begin{array}{c}\text { Liver wt } \\
(\mathrm{g})\end{array}$ & $\begin{array}{c}\text { Liver triglyceride } \\
(\mu \mathrm{mol} / \mathrm{g})\end{array}$ & $\begin{array}{c}\text { Plasma free fatty acid } \\
(\mu \mathrm{mol} / \mathrm{ml})\end{array}$ \\
\hline Maternal & - & - & $1 \cdot 8 \pm 0.42$ & $0.62 \pm 0.2$ \\
Large fetuses & $105 \pm 5 \cdot 6$ & $6 \cdot 1 \pm 0 \cdot 7$ & $49.2 \pm 10 \cdot 9$ & $0.51 \pm 0.12$ \\
Small fetuses & $69 \pm 3 \cdot 2^{* * *}$ & $3 \cdot 8 \pm 0.35^{* * *}$ & $68.7 \pm 8 \cdot 6^{* *}$ & $0.75 \pm 0 \cdot 16^{* * *}$ \\
\hline
\end{tabular}

Simultaneous measurements were made on large and small fetuses from the same litters of 8 guinea-pigs 64-67 days pregnant. Plasma was obtained from umbilical vein blood of the fetuses and inferior vena caval blood of the mothers. Free fatty acids were measured by the method of Duncombe (1963) after extraction from plasma as described by Dole (1956). Triglycerides were measured in tissue extracts, after removal of polar lipids, as the increase in glycerol after saponification. The results are expressed as means \pm S.D.

Significantly different from large fetuses: ${ }^{* *} P<0.01 ;{ }^{* * *} P<0.001$.

\section{Placental function and fetal growth}

The major nutrients in the maternal circulation, such as glucose and amino acids, cross the placenta readily (Szabo \& Grimaldi, 1970). The net quantity transferred is probably related to the concentration in maternal plasma. The permeability of the placenta to other metabolites such as lipids, lactate and ketone bodies in some species is high and in others low (Szabo \& Grimaldi, 1970). The extent to which short-term, physiological fluctuations in nutrients across the placenta regulate fetal growth is not known. Surgical alteration of the blood supply to the placenta is associated with a major reduction in fetal growth rate (see above). In addition, the well known correlation between placental mass and fetal weight (Dawes, 1968) and the growth-retarded lambs of ewes in which the placental mass has been surgically reduced (Alexander, 1964) demonstrate the long-term control of fetal growth by the placenta. This is associated with a reduction in fetal plasma glucose, lactate

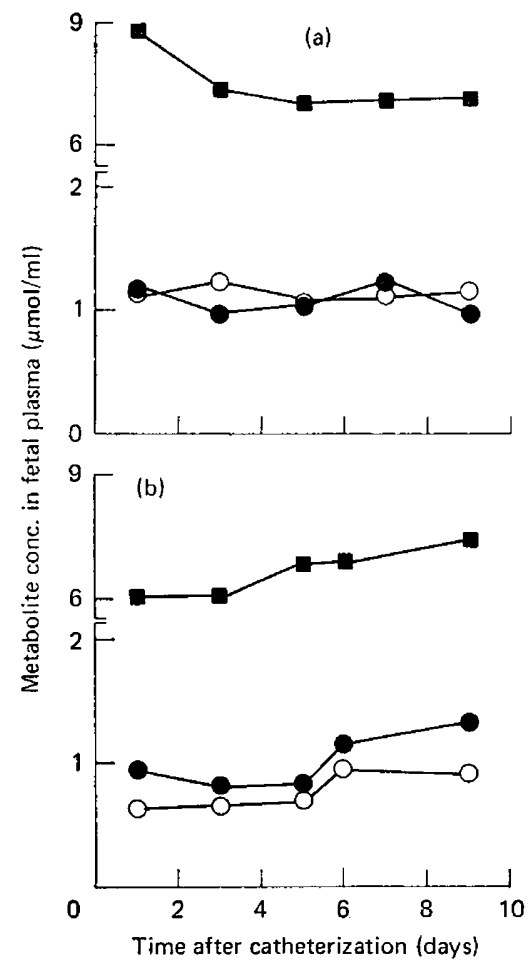

Text-fig. 1. The concentrations of glucose (O), lactate $(\bullet)$ and $\alpha$-amino nitrogen $(\square)$ in the plasma of fetal sheep of (a) normal ewes and (b) ewes with a portion of placental caruncles removed before conception. Plasma metabolite concentrations in the ewes did not change significantly during the period of observation and were similar in each (J. S. Robinson \& C. T. Jones, unpublished observations). 
and amino acid (Text-fig. 1). Thus it seems likely that the rate of supply of nutrients to the fetus in utero may be close to the rate of utilization by the fetus and that a reduction in placental mass and so, presumably, of the maternal blood flow reduces the supply of nutrients for fetal growth.

The placenta through its own metabolism may also influence the composition of the nutrient supply from the maternal circulation. It has the capacity for amino acid metabolism and interconversion, substantial lactate production and the synthesis of lipids (Szabo \& Grimaldi, 1970; Text-fig. 2). Although there are substantial species differences, e.g. the placenta of the rabbit synthesizes lipids from acetate or glucose at a high rate while in that of the guinea-pig lipid synthesis is barely detectable (Text-fig. 3), this aspect of the metabolism of the pregnant animal has not been sufficiently investigated to make a quantitative assessment of the importance of placental metabolism for the fetus. However, in the sheep, placental lactate production may make a substantial contribution to fetal metabolism (Burd et al., 1975). Also, its metabolism and possible metabolic effects on the fetus may be affected by maternal hormones such as insulin (Freinkel, 1965) and maternal nutritional state (Fain \& Scow, 1966).

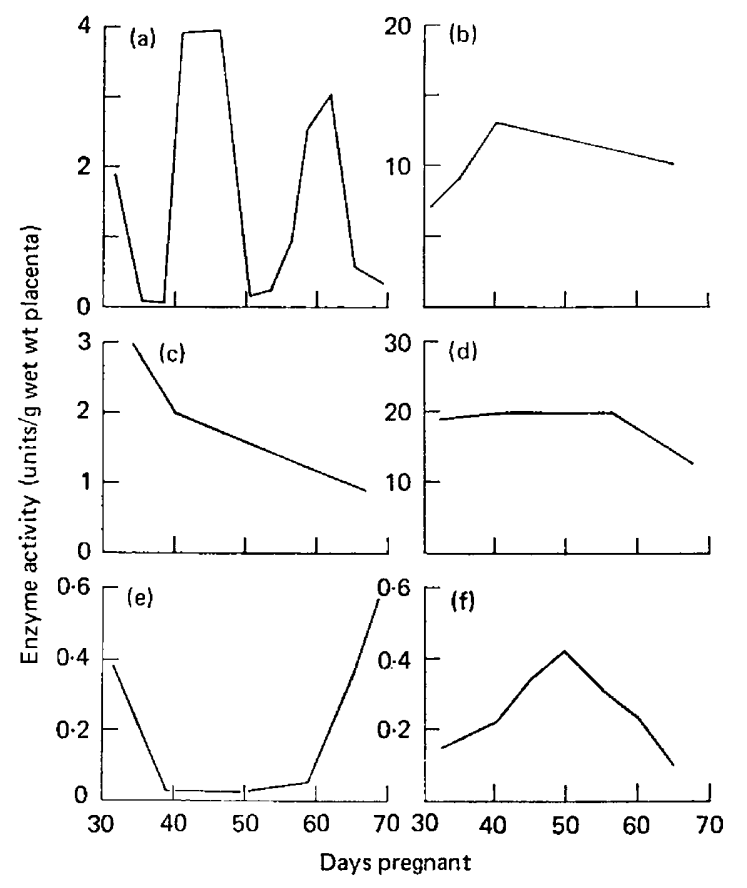

Text-fig. 2. The development of some placental enzymes of the guinea-pig. The activities of (a) alanine aminotransferase, (b) aspartate aminotransferase, (c) hexokinase, (d) glutamate dehydrogenase, (e) fructose 1,6-diphosphatase and (f) ATP-citrate lyase were assayed in the supernatant fraction of homogenized placenta after centrifugation at $30,000 \mathrm{~g}$ for $60 \mathrm{~min}$.

The placenta is also an important site of hormone production for the fetus which is reached by the maternal circulation (Thau \& Lauman, 1975). Placental hormones may exert effects on maternal metabolism (Kaplan \& Grumbach, 1974) that can promote fetal growth, e.g. a shift in the glucose/ insulin relationship in favour of the glucose supply to the fetus (Adams, 1971), or an increase in free fatty acids late in gestation which may be brought about by a number of hormones such as chorionic somatomammotrophin or cortisol to increase the lipid supply to the fetus (Knopp, Saudek, Arky \& O'Sullivan, 1973). The possibility that placental hormones have important direct effects 


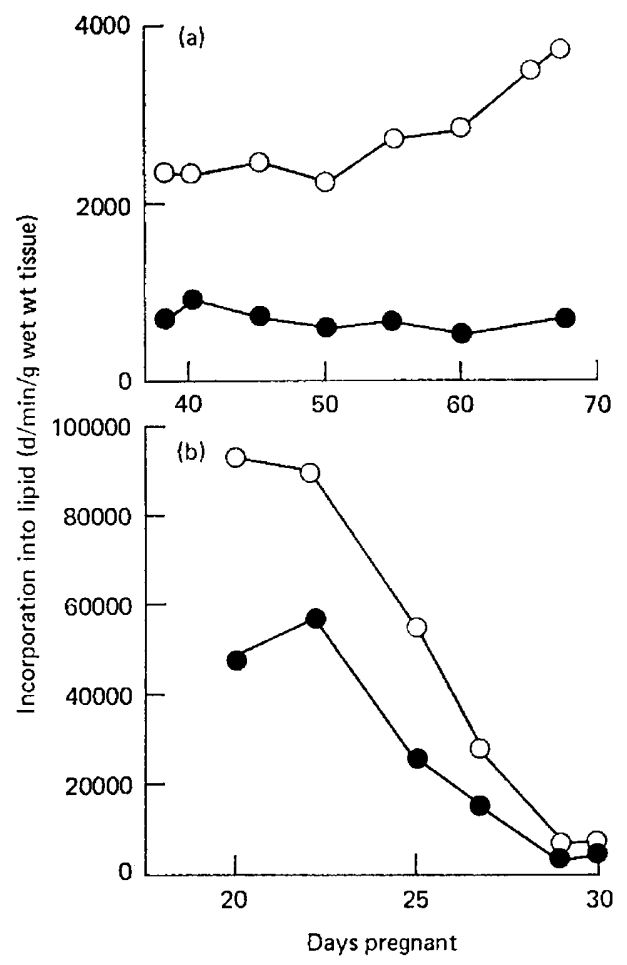

Text-fig. 3. The synthesis of lipids by the placenta of (a) guinea-pigs and (b) rabbits. Slices of placenta were incubated for $90 \mathrm{~min}$ in Krebs bicarbonate buffer (gassed with $95 \% \mathrm{O}_{2}+5 \% \mathrm{CO}_{2}$ ) at $37^{\circ} \mathrm{C}$ with 3.3 mm- $\left[1{ }^{14} \mathrm{C}\right]$ acetate $(O)$ or $10 \mathrm{~mm}-\left[\mathrm{U}-{ }^{14} \mathrm{C}\right]$-glucose $(\bullet)$.

on fetal metabolism remains to be established, as does the nature of some of the hormones secreted by the placenta into the fetal circulation (Saxena, 1971).

Thus it is clear that the placenta, at least in pathological or extreme physiological conditions, has large effects on fetal growth, probably primarily because of its transport functions. Its ability to make compensatory adjustments to the composition of nutrients passing to the fetus or to influence fetal metabolism through hormone action remains, however, to be elucidated.

\section{Fetal metabolism}

It was thought until recently that fetal metabolism was governed solely by the requirement of the fetus to direct amino acids, lipids and primarily glucose into pathways for cell growth and was largely controlled by nutrient supply from the maternal circulation. This view has been supported by the absence of some of the pathways essential for amino acid homeostasis and for glucose synthesis (Greengard, 1971) and the low activity of the pathway for fatty acid oxidation (Warshaw, 1972) in some of the tissues of the fetal rat and rabbit. The metabolic autonomy of the fetus and its ability to compensate for alterations in nutrient supply have been considered therefore to be small.

The assessment of the metabolic autonomy of the fetus must depend on: (a) the presence of pathways in the fetal tissues for some degree of independent metabolic homeostasis; (b) the demonstration of the functional significance of these pathways in vivo; (c) proof that the fetal endocrine glands are capable of functioning independently of the maternal ones to control fetal metabolism; (d) the demonstration that, in conditions in which maternal metabolism or placental function, and hence fetal growth rate, is altered, fetal metabolism and endocrine glands are capable of making compensatory adjustments. 


\section{(a) Pathways for metabolic homeostasis}

In the adult the liver plays a central role in glucose, amino acid and lipid homeostasis (Weber, Singhal, Stamm, Fisher \& Mentendiek, 1964; Newsholme \& Start, 1973). In the fetus glucose has been considered as the major metabolic substrate (Alexander, Britton \& Nixon, 1966), its supply being regulated largely by placental transfer with little need for hepatic or renal gluconeogenesis. This view is supported by the low activity of the gluconeogenic enzymes in the liver of the fetal rat and rabbit (Dawkins, 1966; Ballard \& Hanson, 1967a; Vernon \& Walker, 1968; Usatenko, 1970) and the absence of significant rates of gluconeogenesis until after birth (Ballard \& Oliver, 1965; Yeung \& Oliver, 1967; Snell \& Walker, 1973). In man, guinea-pig, sheep, pig and monkey, gluconeogenic enzymes have been detected in the fetal liver relatively early in gestation (Aurricchio \& Rigollo, 1960; Dawkins, 1966; Wallace \& Newsholme, 1967; Raiha \& Lindros, 1969; Mersmann, 1971 ; Edwards, Dhand, Jeacock \& Shepherd, 1975; Jones \& Ashton, 1976a). Glucose synthesis has also been observed in the fetal guinea-pig, sheep and human liver in vitro (Villee, 1954; Ballard \& Oliver, 1965; Arinze, 1975). Therefore, while it is likely that the majority of glucose comes from the maternal circulation, the fetus may contribute to glucose homeostasis late in gestation.

The role of amino acids in providing precursors for glucose synthesis, respiration or the production of other compounds such as lipids has been considered small because of the low transaminase activity and urea production in fetal rate and rabbit liver (Greengard, 1971; Raiha \& Schwartz, 1973). However, substantial transaminase activity has been observed in the liver of the fetal guineapig (Test-fig. 4) and sheep (Rattenbury, Jeacock \& Shepherd, 1972), and is indicated in the human fetal liver (Raiha \& Suihkonen, 1968). Also, the amino acid supply to the fetal sheep probably represents a major metabolic fuel for respiration (Tsoulos et al., 1971; Gresham et al., 1972).

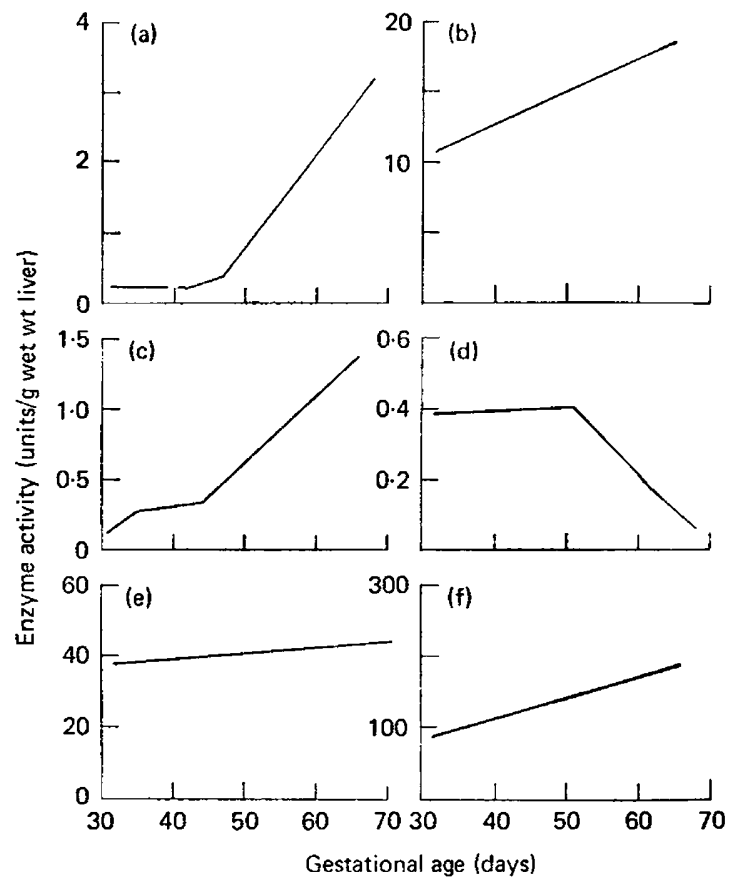

Text-fig. 4. The development of some enzymes of amino acid metabolism in the liver of the guinea-pig. The activities of (a) alanine amino transferase, (b) aspartate amino transferase, (c) tyrosine amino transferase, (d) leucine aminotransferase, (e) glutamate dehydrogenase and (f) arginase were assayed in the supernatant fraction of homogenized liver after centrifugation at $30,000 \mathrm{~g}$ for $60 \mathrm{~min}$.

Fetal tissues, in particular adipose and liver, have high rates of lipid synthesis during a major part of gestation (Villee \& Hagermann, 1958; Roux \& Yoshioka, 1970; Ballard \& Hanson, 1967b; 
Taylor, Bailey \& Bartley, 1967; Jones, 1973; Jones \& Ashton, 1976b). On the other hand, the oxidation of fatty acids by the fetal rat liver and heart is believed to be relatively low (Warshaw, 1972). This is, however, not true for all species, and the monkey and human fetal liver oxidize palmitate at high rates (Villee, Hagermann \& Holmberg, 1958; Roux \& Yoshioka, 1970), as may that of the fetal rat (Taylor et al., 1967).

In some species, therefore, the essential pathways for metabolic homeostasis in which the liver plays a key role in directing glucose, amino acid and lipid metabolism are well developed during fetal life.

\section{(b) The metabolic responses of the fetus in utero}

The fetal guinea-pig or monkey in utero is capable of synthesizing glucose de novo from lactate, pyruvate or amino acids (Stegink, Pitkin, Reynolds, Filer, Boaz \& Brummel, 1975; Text-fig. 5). As already mentioned the fetal sheep probably uses amino acids for respiration to a substantial extent, and this is altered by the nutritional state of the mother (Gresham et al., 1972; Tsoulos et al., 1971). The liver of the fetal guinea-pig in utero controls the distribution of fatty acids from the maternal circulation and may supply lipids to other tissues (Jones, 1973; Jones \& Firmin, 1976).

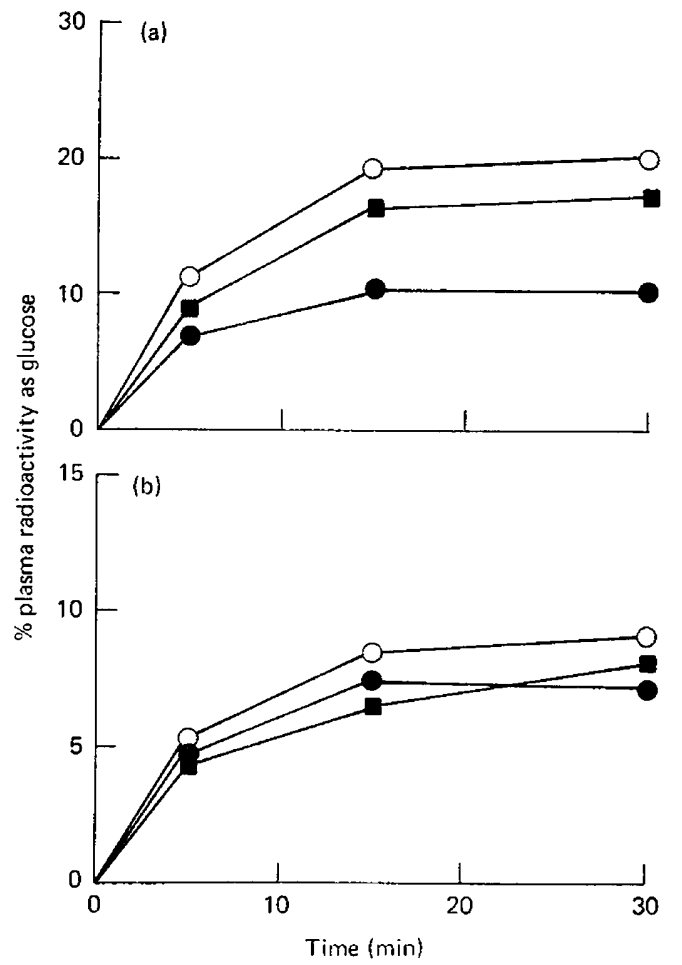

Text-fig. 5. The synthesis of glucose from lactate, pyruvate and alanine by fetal guinea-pigs. The $\left[3-{ }^{14} \mathrm{C}\right]-$ pyruvate $(O)$, [U- $\left.{ }^{14} \mathrm{C}\right]$ lactate $(\bullet)$ and $\left[\mathrm{U}-{ }^{14} \mathrm{C}\right]$ alanine $(\boldsymbol{\sigma})$ were injected into the umbilical vein of fetal guinea-pigs (61 -63 days). The results are expressed as \% of radioactivity recovered as glucose in (a) fetal and (b) maternal plasma.

In situations such as hypoxaemia, where maternal placental blood flow may be reduced (Greiss, Anderson \& King, 1972; Makowski, Hertz \& Meschia, 1973), the fetal sheep responds by increasing its blood glucose, lactase, fatty acid and amino acid concentration (Text-fig. 6). These changes are independent of those occurring in the maternal circulation and can also be produced by catecholamine infusion directly into the fetus (Text-fig. 6). Thus the fetal tissues, by mobilizing substances 


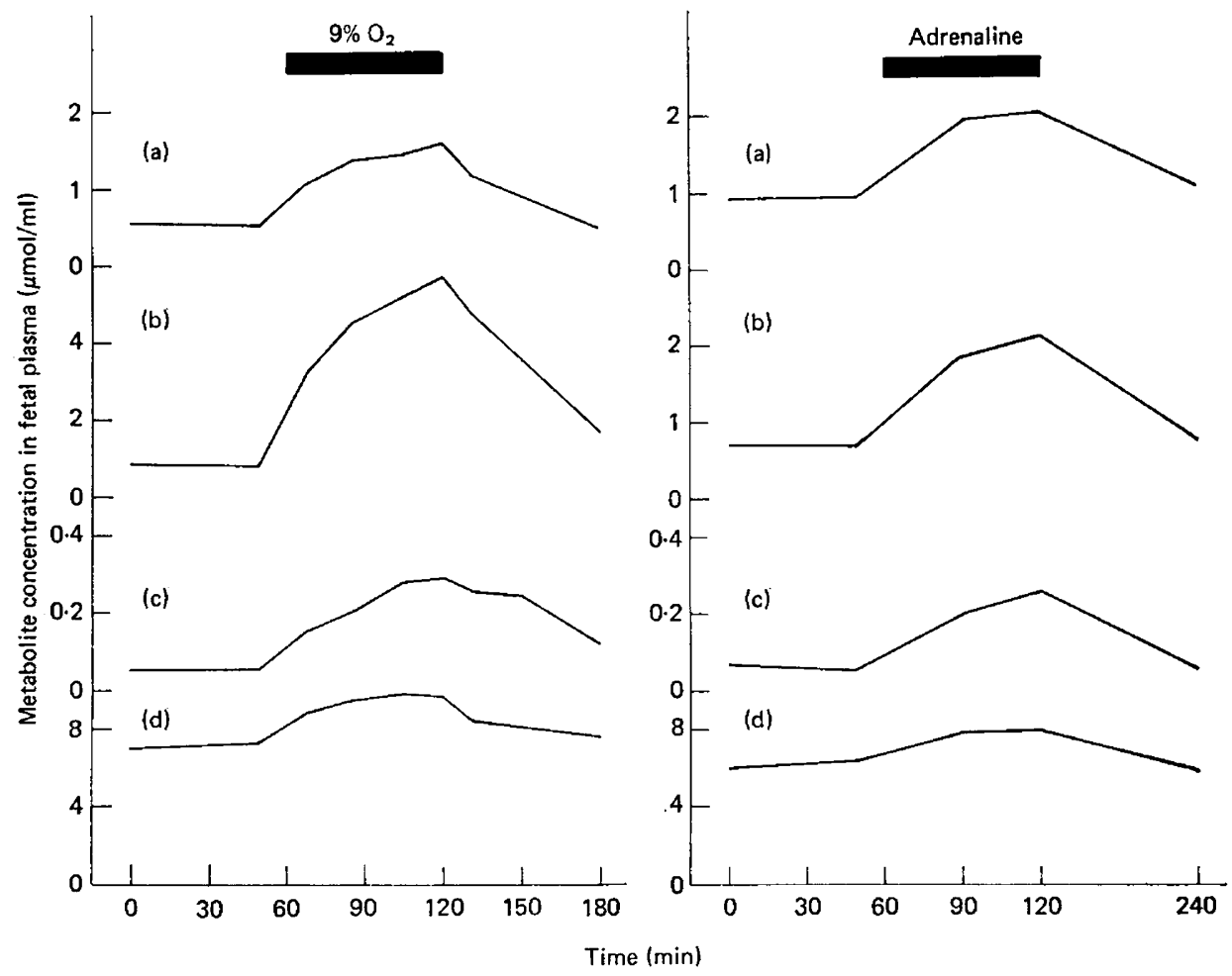

Text-fig. 6. The metabolic response of the fetal sheep to hypoxaemia and catecholamines. The fetus was made hypoxic by the administration of $9 \% \mathrm{O}_{2}$ and $3 \% \mathrm{CO}_{2}$ to a ewe 131 days pregnant, or adrenaline (1.3 $\mu \mathrm{g} / \mathrm{min})$ was infused via the jugular vein of a 128-day fetus. The concentrations of (a) glucose, (b) lactate, (c) free fatty acid and (d) $\alpha$-amino nitrogen were measured in the plasma of the fetus.

such as glycogen or fatty acid, are capable of compensating for some short-term deficiencies in placental supply.

\section{(c) Fetal endocrine control of metabolism}

Of the hormones studied, insulin, glucagon, growth hormone, ACTH and catecholamines do not cross the placenta (Alexander, Britton, Cohen \& Nixon, 1972; Wallace, Stacy \& Thorburn, 1973; Girard, Kervan, Soufflet \& Assan, 1974; Jones, Luther, Ritchie \& Worthington, 1975; Jones \& Robinson, 1975). Maternal hormone secretion is unlikely therefore to influence fetal metabolism directly. This is demonstrated (Text-fig. 7) by the changes in fetal hormones that occur in conditions such as fetal hypoxaemia where, for example the increases in fetal plasma ACTH and catecholamines are quite independent of any changes in the maternal circulation (Boddy, Jones, Mantell, Ratcliffe \& Robinson, 1974; Alexander, Britton, Forsling, Nixon \& Ratcliffe, 1973; Jones, Boddy, Robinson, Ratcliffe, 1975; Jones \& Robinson, 1975). Such independence of the fetal endocrine glands is also demonstrated by the response of the fetal pancreas to conditions such as hypoglycaemia or hyperglycaemia produced by starvation or glucose infusion; fetal plasma insulin changes to control fetal glucose utilization in relation to glucose supply (Chez, Mintz, Horger \& Hutchinson, 1970; Colwill et al., 1970; Bassett \& Madill, 1974a; Shelley, Bassett \& Milner, 1975). These changes are independent of maternal plasma insulin changes and suggest that fetal insulin production may be a major factor in regulating fetal growth (Liggins, 1975; Shelley, 1975).

The sensitivity of the glucose metabolism of some fetal tissues to insulin and catecholamines has been demonstrated in the rat and guinea-pig (Britton \& Blade, 1970; Clark, 1971 ; Boçek, Young \& Beatty, 1973; Eisen, Goldfine \& Glinsmann, 1973). 


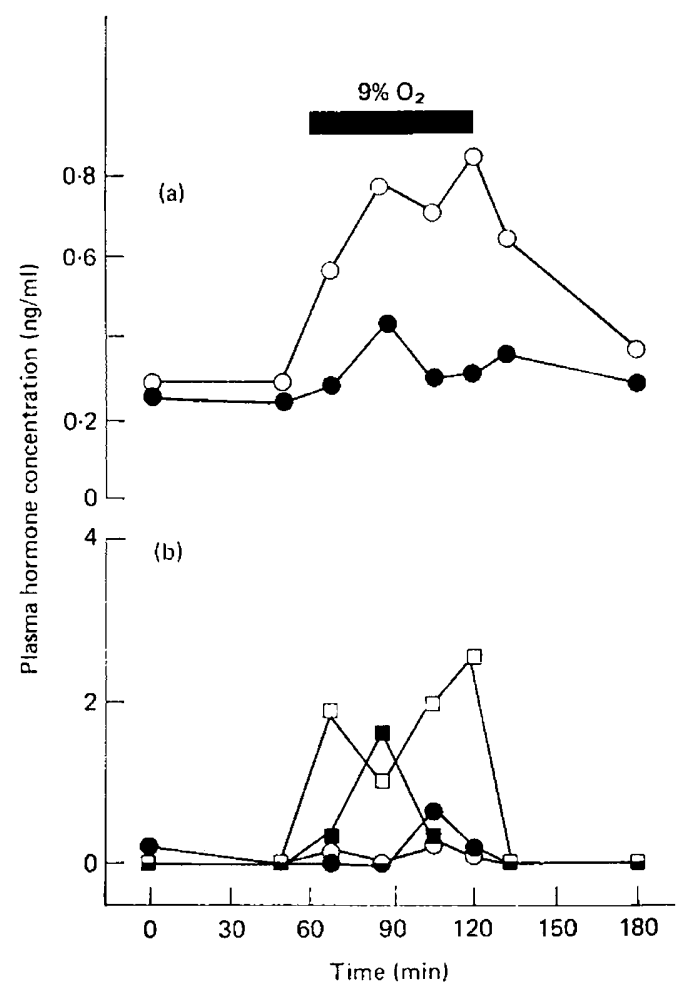

Text-fig. 7. The changes in plasma ACTH (a) and catecholamines (b) during hypoxaemia in fetal and adult sheep. (a) O, fetal ACTH; $\bullet$, maternal ACTH; (b) $\mathbf{n}$, fetal adrenaline; $\square$, fetal noradrenaline; $\bullet$, adult adrenaline; $O$, adult noradrenaline.

Some hormones, notably corticosteroids and possibly thyroid hormones, cross the placenta (Beitius, Kowarski, Shermeta, Delemos \& Migeon, 1970; Osorio \& Myant, 1960; Geloso \& Bernard, 1967) and their transport may provide information to the fetus on the maternal metabolic state. However, there are times, such as before birth, when fetal corticosteroid production may overshadow placental transfer (Bassett \& Thorburn, 1969; Liggins, Fairclough, Grieves, Kendall \& Knox, 1973; Mulay, Giaunopoulos \& Solomon, 1973; Jones, 1974). This preparturient rise in corticosteroids appears to be a major signal for the deposition of glycogen (Jost \& Picon, 1970; Jones, 1974; Text-fig. 8), for the maturation of the fetal lung (Delemos, Shermeta, Knelson, Kotas \& Avery, 1970; Kotas \& Avery, 1971), and changes in lipid storage in fetal tissues (Bohmer, Havel \& Long, 1972; Jones, 1974; Text-fig. 8).

Thus the fetal endocrine glands exhibit a substantial autonomy. They not only modulate the effects of changes in the supply of nutrients from the maternal circulation but also promote specific developmental changes in metabolic pathways.

\section{(d) Compensatory responses of fetal metabolism}

There are few studies demonstrating changes in the nature of fetal metabolism compensating for alterations in nutrient supply. Starvation of the pregnant sheep is probably associated with a shift from glucose to amino acid oxidation (Tsoulos et al., 1971; Gresham et al., 1972) with the reduction in fetal insulin secretion partly responsible (Bassett \& Madill, 1974b). In pregnant rats starvation produces enzyme changes in the brain that favour the metabolism of ketone bodies which are supplied in greater quantities than under normal dietary conditions (Thaler, 1972). Starvation may also depress hepatic fatty acid synthesis in the rat (Fain \& Scow, 1966). These few examples 

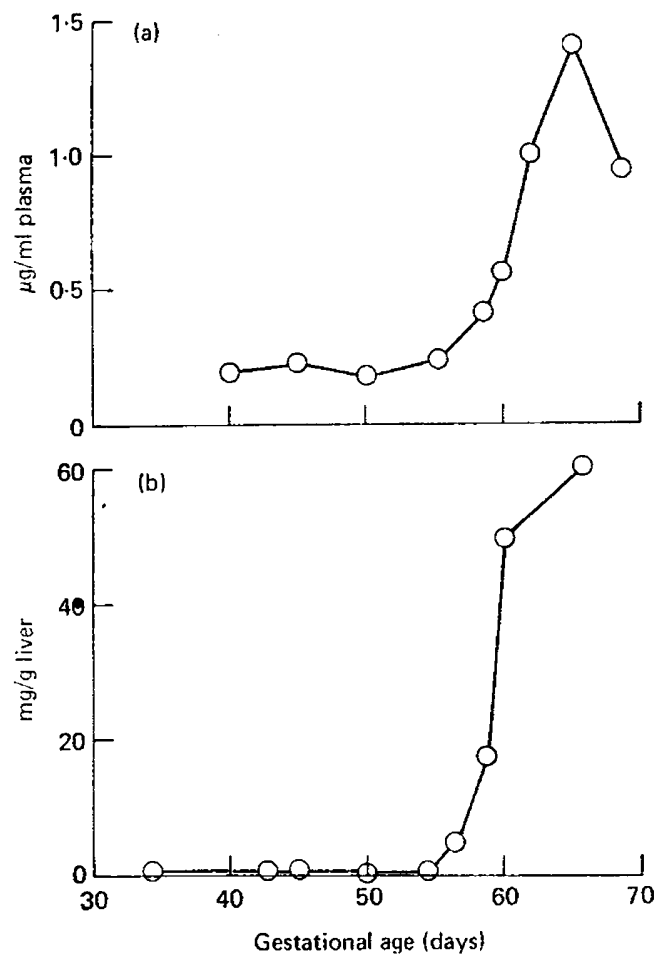

Text-fig. 8. The changes in (a) plasma cortisol and (b) liver glycogen of fetal guinea-pigs during pregnancy.

suggest that the fetus is capable of discrete compensatory adjustments of metabolism, probably largely under its endogenous endocrine control, and made in response to changes in maternal nutrition. Such factors may substantially influence the course of fetal growth. Even within the same litter major differences may occur in fetal metabolism that have some relationship to differing rates of growth (Widdowson, 1974).

In some instances fetal growth retardation may inhibit rather than stimulate the development of a particular metabolic pathway. An example of this is the apparent inhibition of the development of gluconeogenesis in growth-retarded newborn rats (Nitzan \& Groffman, 1971) and small-forgestational-age infants (Haymond, Karl \& Pagliora, 1974).

In conclusion, it is clear at present that maternal metabolism and placental vascular supply and function can have large effects on fetal growth. Some of these may be modulated by fetal metabolism. It is not clear what quantitative contribution the control of metabolism by the fetus makes to directing fetal growth. The fetus appears to possess some of the pathways required to compensate for changes in nutrient supply, at least in the short term.

\section{References}

ADAM, P.A.J. (1971) Control of glucose metabolism in the human fetus and newborn infant. Adv. metab. Disord. 5, 183-275.

Alexander, D.P., Britton, H.G. \& Nixon, D.A. (1966) Observations on the isolated foetal sheep with particular reference to the metabolism of glucose and fructose. J. Physiol., Lond. 185, 382-399.

Alexander, D.P., Britton, H.G., Cohen, N.M. \& Nixon, D.A. (1972) The permeability of the sheep placenta to insulin. Studies with the perfused placental preparation. Biol. Neonate 21, 361-368. 
Alexander, D.P., Britton, H.G., Forsling, M.L., Nixon, D.A. \& Ratcliffe, J.G. (1973) Adrenocorticotrophin and vasopressin in foetal sheep and the response to stress. In The Endocrinology of Pregnancy and Parturition, pp. 112-125. Ed. C. G. Pierrepoint. Alpha Omega Alpha Publishing, Cardiff.

Alexander, G. (1964) Studies on the placenta of the sheep (Ovis aries L.). Effect of surgical reduction in the number of caruncles. J. Reprod. Fert. 7, $307-322$.

ARINZE, I.J. (1975) On the development of phosphoenolpyruvate carboxykinase and gluconeogenesis in guinea-pig liver. Biochem. Biophys. Res. Commun. 65, 184-189.

Aurricchio, S. \& Rigollo, N. (1960) Glucose 6phosphatase activity of the human foetal liver. Biol. Neonate 2, 146-148.

BAIRD, J.D. (1969) Some aspects of carbohydrate metabolism in pregnancy with special reference to the energy metabolism and hormonal status of the diabetic woman and the diabetogenic effects of pregnancy. J. Endocr. 44, 139-172.

Ballard, F.J. \& Hanson, R.W. (1967a) Phosphoenolpyruvate carboxykinase and pyruvate carboxylase in developing rat liver. Biochem. J. 104, 866-871.

BallaRd, F.J. \& HaNSON, R.W. (1967b) Changes in lipid synthesis in rat liver during development. Biochem. J. 102, 952-958.

Ballard, F.J. \& Oliver, I. T. (1976) Carbohydrate metabolism in liver from foetal and neonatal sheep. Biochem. J. 95, 191-200.

BASSET, J.M. \& MADILL, D. (1974a) Influence of prolonged glucose infusion on plasma insulin and growth hormone concentrations in foetal lambs. J. Endocr. 62, 299-309.

Bassett, J.M. \& MAdill, D. (1974b) The influence of maternal nutrition on plasma hormone and metabolite concentrations in foetal lambs. $J$. Endocr. 61, $465-477$.

Bassett, J.M. \& Thorburn, G.D. (1969) Foetal plasma corticosteroids and the initiation of parturition in sheep. J. Endocr. 44, 285-286.

Battaglia, F.C. \& Meschia, G. (1973) Foetal metabolism and substrate utilization. In Foetal and Neonatal Physiology, pp. 382-397. Eds K. S. Comline, K. W. Cross, G. S. Dawes \& P. W. Nathanielsz. Cambridge University Press.

Beitius, I.Z., Kowarskr, A., Shermeta, D.W., Delemos, R.A. \& Migeon, C.J. (1970) Fetal and maternal secretion rate of cortisol in sheep: diffusion resistance of the placenta. Pediat. Res. 4, 129-134.

Bocek, R.M., Young, M.K. \& Beatty, C.H. (1973) Effect of insulin and epinephrine on the carbohydrate metabolism and the adenylate cyclase activity of the rhesus fetal muscle. Pediat. Res. 7, 787793.

Boddy, K., Jones, C.T., Mantell, C., Ratcliffe, J.G. \& Robinson, J.S. (1974) Changes in plasma ACTH and corticosteroid of the maternal and fetal sheep during hypoxia. Endocrinology 94, 588-591.

Bohmer, T., Havel, R.J. \& LoNG, J.A. (1972) Physiological fatty liver and hyperlipemia in the fetal guinea-pig: chemical and ultrastructural characterization. J. Lipid Res. 13, 371-382.
Britton, H.G. \& BlAde, M. (1970) The incorporation of radioglucose into glycogen in foetal and neonatal rat diaphragm in vitro: the effect of insulin. Biol. Neonate 16, 370-375.

Burd, L.I., Jones, M.D., Simmons, M.A., Makowski, E.L., Meschia, G. \& Battaglia, F.C. (1975) Placental production and foetal utilization of lactate and pyruvate. Nature, Lond. 254, 710-711.

CARDell, B.S. (1953) Infants of diabetic mothers. A morphological study. J. Obstet. Gynaec. Br. Emp. 60, 834-853.

Chase, H.P., Dabiere, C.S., Welch, N.N. \& O'Brien, D. (1971) Intra-uterine undernutrition and brain development. Pediatrics, Springfield 47, 491-500.

Chez, R.A., Mintz, D.H., Horger, E.O. \& HutchinsoN, D.L. (1970) Factors affecting the response to insulin in the normal subhuman pregnant primate. J. clin. Invest. 49, 1517-1527.

Clark, C.M. (1971) Carbohydrate metabolism in the isolated fetal rat heart. Am. J. Physiol. 220, 583-588.

Colwill, J.R., Davis, J.R., Meschia, G., Makowski, E.L., Beck, P., \& Battaglia, F.C. (1970) Insulininduced hypoglycemia in ovine fetus in utero. Endocrinology 87, 710-715.

Cornblath, M. \& Schwartz, R. (1966) Disorders of Carbohydrate Metabolism in Infancy, pp. 57-81. Saunders, Philadelphia \& London.

DAwes, G.S. (1968) Foetal and Neonatal Physiology. Year Book Medical Publishers, Chicago.

Dawkins, M.J.R. (1966) Biochemical aspects of developing functions in newborn mammalian liver. $B r$. med. Bull. 22, 27-33.

Delemos, R., Shermeta, D., Knelson, J., Kotas, R. \& AVERY, M. (1970) Acceleration of appearance of pulmonary surfactant in the fetal lamb by administration of corticosteroids. Am. Rev. Resp. Disord. $102,459-461$.

DOLE, V.P. (1956) A relation between non-esterified fatty acids in plasma and the metabolism of glucose. $J$. clin. Invest. 35, 150-154.

Duncomse, W.G. (1963) The colorimetric microdetermination of long-chain fatty acids. Biochem. J. 88, 7-10.

Edson, J.L., Hudson, D.G. \& Hull, D. (1975) Evidence for increased fatty acid transfer across the placenta during a maternal fast in rabbits. Biol. Neonate 27, 50 55.

Edwards, E.M., Dhand, U.K., Jeacock, M.K. \& SHEPHERD, D.A.L. (1975) Activities of enzymes concerned with pyruvate and oxaloacetate metabolism in the heart and liver of developing sheep. Biochim. biophys. Acta 399, 217-227.

Eisen, H.J., Goldfine, I.D. \& GlinsmanN, W.H. (1973) Regulation of hepatic glycogen synthesis during fetal development: roles of hydrocortisone, insulin and insulin receptors. Proc. natn. Acad. Sci., U.S.A. 70, 3454-3457.

Emmanouilides, G.C., Townsend, D.E. \& Bauer, R.A. (1968) Effects of single umbilical artery ligation in the lamb fetus. Pediatrics, Springfield 42, 919-925.

Essex, N.L., Pyke, D.A., Watkins, P.J., Brudenell, J.M. \& GAMSU, H.R. (1973) Diabetic pregnancy. Br. med. J. 4, 89-93. 
FAIN, J.N. \& Scow, R.O. (1966) Fatty acid synthesis in vivo in maternal and fetal tissues in the rat. Am. J. Physiol. 210, 19-25.

Fee, B.A. \& WeIL, W.B. (1963) Body composition of infants of diabetic mothers by direct analysis. Ann. N.Y. Acad. Sci. 110, 869-897.

Freinkel, N. (1965) Effects of the conceptus on maternal metabolism during pregnancy. In On the Nature and Treatment of Diabetes, pp. 679-691. Eds B. S. Leibel \& G. A. Wrenshall. Excerpta Medica, Amsterdam.

Geloso, J.P. \& Bernard, G. (1967) Effets de l'ablation de la thyroide maternelle ou foetale sur le taux des hormones circulantes chez le foetus de rat. Acta endocr., Copenh. 56, 561-566.

Girard, J.R., Kervan, A., Soufflet, E. \& Assan, R. (1974) Factors affecting the secretion of insulin and glucagon by the rat fetus. Diabetes 23, 310-317.

GlinsmanN, W.H., Eisen, H.J., LyNCH, A. \& Chez, R.A. (1975) Glucose regulation by isolated near term fetal monkey liver. Pediat. Res. 9, 600-604.

GrefNGARD, O. (1971) Enzymic differentiation in mammalian tissues. Essays in Biochemistry 7, 159-205.

Greiss, F.C., ANderson, S.G. \& KING, L.C. (1972) Uterine vascular bed: effects of acute hypoxia. Am. J. Obstet. Gynec. 113, 1057-1064.

Gresham, E.L., James, E.J., Raye, J.R., Battaglia, F.C., MakowsKi, E.L. \& Meschia, G. (1972) Production and excretion of urea by the fetal lamb. Pediatrics, Springfield 50, 372-379.

Haymond, M.W., Karl, I.E. \& Pagliora, A.S. (1974) Increased gluconeogenic substrates in the small-for-gestational-age infant. New Engl. J. Med. 291, 322-328.

HiLl, D.E. (1974) Experimental growth retardation in rhesus monkeys. In Size at Birth: Ciba Foundn Symp. No. 27, pp. 99-113. Eds K. Elliott \& J. Knight. Elsevier, Amsterdam.

Honenauer, L. \& OH, W. (1969) Body composition in experimental growth retardation in the rat. $J$. Nutr. 99, 23-26.

JoNES, C.T. (1973) The development of lipogenesis in the fetal guinea-pig. In Foetal and Neonatal Physiology, pp. 403-409. Eds R. S. Comline, K. W. Cross, G. S. Dawes \& P. W. Nathanielsz. Cambridge University Press.

JoNes, C.T. (1974) Corticosteroid concentrations in the plasma of fetal and maternal guinea pigs during gestation. Endocrinology 95, 1129-1133.

Jones, C.T. \& Ashton, L.K. (1976a) The appearance, properties and functions of gluconeogenic enzymes in the liver and kidney of the guinea-pig during fetal and early neonatal development. Archs Biochem. Biophys. (In press.)

JONES, C.T. \& Ashton, I.K. (1976b) Lipid biosynthesis in the liver of the fetal guinea-pig. Biochem. J. 154, 149-158.

JONES, C.T. \& FIRMIN, W. (1976) Fatty acid synthesis in vivo by tissues of the maternal and fetal guinea pig. Biochem. J. 154, 159-161.

Jones, C.T. \& RoBinson, R.O. (1975) Plasma catecholamines in foetal and adult sheep. J. Physiol., Lond. 248, 15-33.
Jones, C.T., Boddy, K., Robinson, J.S. \& RATCLIFFe, J.G. (1975) Pituitary and adrenal function in foetal sheep during the latter half of gestation. J. Endocr. 67, 26P.

JONES, C.T., Luther, E., RitchiE, J.W.K. \& WORTHINGTON, D. (1975) The clearance of ACTH from the plasma of adult and fetal sheep. Endocrinology 96, 231-234.

Jost, A. \& Picon, L. (1970) Hormonal controls of fetal development and metabolism. Adv. Metab. Disorders $4,123-184$.

Kaplan, S.L. \& Grumbach, M.M. (1974) Effects of primate chorionic somatomammotropin on maternal and fetal metabolism. In Lactogenic Hormones, Fetal Nutrition and Lactation, pp. 183-191. Eds J. B. Losimovich, M. Reynolds \& E. Cobo. Academic Press, New York \& London.

Knopp, R.H., SAudek, C.D., ARky, R. \& O'Sullivan, J.B. (1973) Two phases of adipose tissue metabolism in pregnancy: maternal adaptation for fetal growth. Endocrinology 92, 984-993.

KotAs, R.V. \& AVERY, M.E. (1971) Accelerated appearance of the pulmonary surfactant in the fetal rabbit. J. appl. Physiol. 30, 358-361.

LeE, C.J. \& Chow, B.F. (1965) Protein metabolism in the offspring of underfed mother rats. J. Nutr. 87, 439-443.

LigGins, G.C. (1974) The influence of the fetal hypothalamus and pituitary on growth. In Size at Birth: Ciba Foundn Symp. No. 27, pp. 165-183. Eds K. Elliott \& J. Knight. Elsevier, Amsterdam.

Liggins, G.C., Fairclough, R.J., Grieves, S.A., KeNDALl, J.Z. \& KNOX, B.S. (1973) The mechanism of initiation of parturition in the ewe. Recent Prog. Horm. Res. 29, 111-150.

Makowski, E.L., Hertz, R.H. \& Meschia, G. (1973) Effects of acute maternal hypoxia and hyperoxia on the blood flow to the pregnant uterus. $A m$. J. Obstet. Gynec. 115, 624-631.

MersmanN, H.J. (1971) Glycolytic and gluconeogenic enzyme levels in pre- and postnatal pigs. $A \mathrm{~m}$. J. Physiol. 220, 1297-1302.

Mintz, D.H., Chez, R.A. \& Hutchinson, D.L. (1972) Sub-human primate pregnancy complicated by streptozotocin-induced diabetes mellitus. $J$. clin. Invest. 51, 837-847.

Mulay, S., Giaunopoulos, G. \& Solomon, S. (1973) Corticosteroid levels in the mother and fetus of the rabbit during gestation. Endocrinology 93, 13421348.

NAEYe, R.L. (1965) Infants of diabetic mothers: a quantitative morphologic study. Pediatrics, Springfield 35, 980-988.

Newsholme, E.A. \& StaRT, C. (1973) Regulation in Metabolism. J. Wiley, London.

Nitzan, M. \& Groffman, H. (1971) Hepatic gluconeogenesis and lipogenesis in experimental intrauterine growth retardation in the rat. Am.J. Obstet. Gynec. 109, 623-627.

Nitzan, M. \& Groffman, H. (1974) Glucose metabolism in experimental intrauterine growth retardation in vivo. Studies with liver and brain slices. Biol. Neonate 17, 420-426. 
OAKLEY, W.G. (1965) The treatment of pregnancy in diabetes mellitus. In On the Nature and Treatment of Diabetes, pp. 673-678. Eds B. S. Leibel \& G. A. Wrenshall. Excerpta Medica, Amsterdam.

OH, W., D'Amodio, M.D., YaP, L.L. \& Honenauer, L. (1970) Carbohydrate metabolism in experimental intrauterine growth retardation. Am. J. Obstet. Gynec. 108, 415-421.

OsLER, M. (1965) Structural and chemical changes in infants of diabetic and pre-diabetic mothers. In On the Nature and Treatment of Diabetes, pp. 692-699. Eds B. S. Leibel \& G. A. Wrenshall. Excerpta Medica, Amsterdam.

Osorio, C. \& MYANT, N.B. (1960) The passage of thyroid hormone from mother to foetus and its relation to foetal development. Br. med. Bull. 16, 159-164.

Pederson, J. (1967) The Pregnant Diabetic and her Newborn. Munksgaard, Copenhagen.

Persson, B. (1974) Assessment of metabolic control in diabetic pregnancy. In Size at Birth: Ciba Foundn Symp. No. 27, pp. 247-267. Eds K. Elliott \& J. Knight. Elsevier, Amsterdam.

Raiha, N.C.R. \& Lindros, K.O. (1969) Development of some enzymes involved in gluconeogenesis in human liver. Annls Med.exp. Biol. Fenn. 47, 146-148.

RaiHA, N.C.R. \& SChWARTZ, A.L. (1973) Development of urea biosynthesis and factors influencing the activity of the arginine synthetase system in perinatal mammalian liver. In Inborn Errors of Metabolism, pp. 221-233. Eds F. A. Hommes \& C. J. Van Den Berg. Academic Press, London \& New York.

Raiha, N.C.R. \& SUIhKonEN, J. (1968) Development of urea synthesising enzymes in human liver. Acta paed. scand. 57, 121-129.

Rattenbury, J.M., Jeacock, M.K. \& Shepherd, D.A.L. (1972) Ornithine metabolism in the developing sheep. Biochem. J. 128, 143P.

Roux, J.F. \& YoshiokA, T. (1970) Lipid metabolism in the fetus during development. Clin. Obstet. Gynec. 13, 595-620.

Roux, J.M., Tordet-Caridroit, C. \& Chanez, C. (1970) Studies on experimental hypertrophy in the rat. I. Chemical composition of the total body and some organs in the rat foetus. Biol. Neonate 15, 342-347.

Saxena, B.N. (1971) Protein-polypeptide hormones of the human placenta. Vitams. Horm. 29, 95-151.

Shelley, H.J. (1975) Insulin and the control of plasma glucose concentration in chronically catheterized foetal lambs. J. Physiol., Lond. 251, $71 \mathrm{P}$.

Shelley, H.J., Bassett, J.M. \& MilNeR, R.D.G. (1975) Control of carbohydrate metabolism in the fetus and newborn. Br. med. Bull. 31, 37-43.

SNell, K. \& WALKer, D.G. (1973) Gluconeogenesis in the newborn rat: the substrates and their quantitative significance. Enzyme 15, 40-81.

Stave, U. (1970) Physiology of the Perinatal Period. Vols I \& II. Appleton-Century-Croft, New York.

Stegink, L.D., PitKin, R.M., Reynolds, W.A., Filer, L.J., BOAZ, D.P. \& BRUMMEL, M.C. (1975)
Placental transfer of glutamate and its metabolite in the primate. Am. J. Obstet. Gynec. 122, 70-78.

SzaBo, A.J. \& Grimaldi, R.D. (1970) The metabolism of the placenta. Adv. met. Disord. 4, 185-228.

ThaU, R.B. \& Lauman, J.T. (1975) Endocrinological aspects of placental function. In The Placenta and its Maternal Supply Line. Effects of Insufficiency on the Fetus, pp. 123-144. Ed. P. Gruenwald. Med. \& Tech. Publishers, Lancaster.

Taylor, C.B., Bailey, E. \& Bartley, W. (1967) Changes in hepatic lipogenesis during development of the rat. Biochem. J. 105, 717-722.

ThALER, M.M. (1972) The effects of starvation on normal development of $\beta$-hydroxybutyrate dehydrogenase activity in foetal and newborn rat brain. Nature, New Biol. 236, 140-142.

Tsoulos, N.G., Colwill, J.R., Battaglia, F.C., MakowsKi, E.L. \& Meschia, G. (1971) Comparison of glucose, fructose and $\mathrm{O}_{2}$ uptakes by fetuses of fed and starved ewes. Am. J. Physiol. 221, 234-237.

USATENKo, M.S. (1970) Hormonal regulation of phosphoenolpyruvate carboxykinase activity in liver and kidney of adult animals and formation of this enzyme in developing rabbit liver. Biochem. Med. 3, 298-310.

Vernon, R.G. \& Walker, D.G. (1968) Changes in activity of some enzymes involved in glucose utilization and formation in developing rat liver. Biochem. J. 106, 321-329.

VILLEE, C.A. (1954) Intermediary metabolism of human fetal tissues. Cold Spring Harb. Symp. quant. Biol. 19, 186-199.

Villee, C. A. \& Hagerman, P.D. (1958) Effect of oxygen deprivation on the metabolism of fetal and adult tissues. Am. J. Physiol. 194, 457-464.

Villee, C.A., Hagerman, D.D. \& HolmberG, N. (1958) The effects of anoxia on the metabolism of human fetal tissues. Pediatrics, Springfield 22, 953-961.

Wallace, A.L.C., Stacy, B.D. \& Thorburn, G.D. (1973) Regulation of growth hormone secretion in the ovine foetus. $J$. Endocr. 58, 89-95.

W allace, N. \& Newsholme, E.A. (1967) A comparison of the properties of fructose 1,6-diphosphatase, and the activities of other key enzymes of carbohydrate metabolism in the livers of embryonic and adult rat, sheep and domestic fowl. Biochem. $J$. 104, 378-385.

WARSHAW, J.B. (1972) Cellular energy metabolism during fetal development. IV. Fatty acid activation acetyl transfer and fatty acid oxidation during development of the chick and tat. Devl Biol. 28, 537-542.

Weber, G., Singhal, R.L., Stamm, N.B., Fisher, E.A. \& MentendieK, M.A. (1964) Regulation of enzymes involved in gluconeogenesis. $A d v$. Enz. Regul. 2, 1-38.

Widdowson, E.M. (1974) Immediate and long-term consequences of being large or small at birth: a comparative approach. In Size at Birth: Ciba Foundn Symp. No. 27, pp. 65-76. Eds K. Elliott \& J. Knight. Elsevier, Amsterdam. 
WigglesworTh, J.S. (1964) Experimental growth retardation in the foetal rat. J. Path. Bact. 88, 1-13.

YeunG, D. \& OLIVER, I.T. (1967) Gluconeogenesis from amino acids in neonatal rat liver. Biochem. $J$. 103, 744-748.
Zamenhof, S., Van Marthens, E. \& Margolis, F.L. (1968) DNA (cell number) and protein in neonatal brain: alteration by maternal dietary protein restriction. Science, N.Y. 160, 322-323. 